\title{
PEMANFAATAN DAN EKONOMI LONTAR BAGI MASYARAKAT DI KOTA KUPANG
}

\author{
Marlistiyati", Mahayasa", Marthen R Pelokila* \\ ${ }^{1}$ Jurusan Ilmu Lingkungan, Universitas Nusa Cendana \\ *Email : marlisperada1984@gmail.com
}

\begin{abstract}
This study was a descriptive study aimed to describe the form of the utilization of palm and its products as well as economic value is given, while also seeing how the other benefits of ejection for the surrounding environment, as well as how the shape of preservation for plants papyrus remain. This study was conducted in five village spread over 2 sub-district in the city of Kupang Namely District of Kelapa Lima (Ex. Oesapa and Kel. Lasiana), District Maulafa (Ex. Maulafa, Ex. Naimata, Ex. Penfui). The results showed that the population of ejection in the city of Kupang decreased dramatically due to the logging in the region much overgrown palm trees for the construction of both the tourist and residential., Selin was also in the utilization of palm majority of people take advantage of ejection based on knowledge own. Forms of utilization of ejection by the public more on making laru (alcoholic beverage) compared to utilization in other forms such as the manufacture of sugar and liquid sugar plate. It also forms other uses by the community that is in the manufacture of woven still own consumption and has not been introduced to the outside world, although there is the result of webbing that has been introduced to the international level (sasando) but even that would be done by a small group, while when seen in a tree palm has many benefits that can help improve the local economy. Research results also showed a lack of government attention to forms of utilization of these palm trees. Lontar will have value and economic benefit is higher when papyrus was given attention and assistance for people in their utilization thus increase the economic value to the community beneficiaries ejection. Based on these results submitted suggestions like society, the government and all parties concerned to keep attention ejection as one of the typical existing plants NTT. For the government dfan the relevant agencies need to continue to do the socialization and assistance to the community in terms of pemafaatan, processing and marketing of products or product ejection to be better known by the outside world and also needs to be an understanding for the community in the efforts to the preservation of plants palm that because other than plant papyrus that have direct benefits, papyrus also has services for the environment, so that the existence of ejection is maintained.
\end{abstract}

Keywords: porticoed pemfaatan; economic value; conservation efforts

\begin{abstract}
Abstrak
Penelitian ini adalah penelitian deskriptif yang bertujuan untuk mendeskripsikan bentuk pemanfaatan hasil lontar serta produknya dan juga nilai ekonomi yang diberikan, selain itu juga melihat bagaimana manfaat lain dari lontar bagi lingkungan sekitarnya, serta bagaimana bentuk pelestariannya agar tanaman lontar ini terjaga.Penelitian ini dilaksanakan di 5 Kelurahan yang tersebar di 2 Kecamatan yang ada di Kota Kupang Yaitu Kecamatan Kelapa Lima (Kel. Oesapa dan Kel. Lasiana), Kecamatan Maulafa ( Kel. Maulafa, Kel. Naimata, Kel. Penfui ). Hasil penelitian menunjukan bahwa populasi lontar
\end{abstract}


yang ada di Kota Kupang mengalami penurunan drastis disebabkan karena adanya penebangan pada kawasan yang banyak di tumbuhi pohon lontar untuk pembangunan baik itu tempat wisata maupun perumahan., selin itu juga dalam pemanfaatan hasil lontar sebagian besar masyarakat memanfaatkan lontar berdasarkan pengetahuan sendiri. Bentuk pemanfaatan lontar oleh masyarakat lebih banyak pada pembuatan laru (minuman beralkohol) dibandingkan dengan pemanfaatan dalam bentuk lain seperti pembuatan gula lempeng maupun gula cair. Selain itu juga bentuk pemanfaatan lain oleh masyarakat yaitu dalam pembuatan anyaman yang masih dikonsumsi sendiri dan belum diperkenalkan kepada dunia luar, meskipun ada hasil anyaman yang sudah diperkenalkan sampai ke tingkat internasional (sasando) akan tetapi itupun hanya dilakukan oleh sekelompok kecil, sementara apabila dilihat pohon lontar mempunyai banyak manfaat yang dapat membantu meningkatkan ekonomi masyarakat. Hasil penelitan juga menunjukan kurangnya perhatian pemerintah terhadap bentuk pemanfaatan dari pohon lontar ini. Lontar akan mempunyai nilai manfaat dan ekonomi yang lebih tinggi apabila lontar diberi perhatian dan pendampingan bagi masyarakat dalam pemanfaatannya sehingga meningkatakan nilai ekonomi bagi masyarakat pemanfaat lontar. Berdasarkan hasil penelitian ini diajukan saran bagai masyarakat, pemerintah, maupun semua pihak yang terkait agar tetap memperhatikan lontar sebagai salah satu tanaman khas yang ada NTT. Bagi pemerintah dfan pihak instansi terkait perlu terus dilakukan sosialisasi dan pendampingan bagi masyarakat dalam hal pemafaatan, pengolahan serta pemasaran hasil atau produk lontar agar lebih dikenal oleh dunia luar dan juga perlu diberi pemahaman bagi masyarakat dalam pula upaya pelestarian dari tanaman lontar tersebut oleh karena selain tanaman lontar yang mempunyai manfaat secara langsung, lontar juga mempunyai jasa bagi lingkungan, sehingga eksistensi lontar tetap terjaga.

Kata kunci: bantuk pemfaatan; nilai ekonomi; upaya pelestarian

\section{Pendahuluan}

Penyebaran pohon lontar di Kota Kupang terbilang cukup luas akan tetapi pemanfatan dan pengelolaannya yang sampai saat ini masih belum maksimal sehingga belum menjadi sesuatu yang dapat membantu untuk meningkatkan taraf ekonomin masyarakat, sementara apabila di lihat dari segi manfaatnya tanaman lontar mempunyai nilai ekonomi yang cukup besar yang dapat meningkatkan perekonomian serta kesejahteraan masyarakat Kota Kupang.

Dari jumlah atau populasi lontar agak sukar untuk diperkirakan, karena banyak dan penyebarannya sangat luas atau terpencar dan belum ada perhatian untuk menghitungnya. Data BPS NTT dalam Tambunan (2009) memperkirakan jumlah atau populasi lontar adalah 4.000.000 pohon yang terdiri dari tumbuhan muda (< 10 tahun) sebanyak 950.000 pohon dan tumbuhan dewasa (> 10 tahun) sebanyak 3.050 .000 pohon.
Berdasarakan data dari Balai Penelitian Kehutanan Kupang (2014) menunjukan kemampuan menyerap karbon savana lontar di NTT adalah $1.570 .268,64$ ton. Pohon lontar dapat menyimpan karbon selama beberapa dekade dengan syarat tidak terjadi penebangan dalam skala yang luas sehingga tidak terjadi penurunan stok tegakan. Oleh karena itu perlu diperhatikan dalam pengelolaan savana baik lontar maupun gewang karena saat ini terus menerus dilakukan penebangan tanpa dilakukan permudaan atau upaya pelestarian. Perkiraan data dasar untuk savana menunjukkan adanya potensi yang besar untuk memanfaatkan ekosistemnya sebagai penyimpan karbon. Perhatian seharusnya diberikan terhadap seberapa besar karbon dapat tersimpan apabila savana-savana dilindungi dari kebakaran dan penggembalaan ternak, sehingga akumulasi karbon dapat berlangsung. 


\section{Metodologi}

Lontar bagi masyarakat NTT adalah tumbuhan serbaguna, khususnya bagi sebagian masyarakat di Kota Kupang, pulau Rote dan pulau sabu. Pada daerah-daerah tersebut lontar mempunyai peranan yang sangat penting dalam kehidupan sosial penduduk. Sebagian dari masyarakat menggantungkan kehidupannya pada hasil dari lontar, mulai dari daun, buah, nira dan batang. Hasil-hasil lontar tersebut dimanfaatkan untuk memenuhi kebutuhan hidup. Pemanfatan lontar secara umum untuk kepentingan ekonomi, sosial, dan budaya. Manfaat sosial budaya berupa pendidikan, penelitian, informasi dan wisata. Menurut Pellokila dalam Asrial (2008), hampir seluruh bagian dari tumbuhan lontar dapat digunakan untuk berbagai keperluan seperti bahan bangunan, perabot rumah tangga dan barangbarang kesenian /budaya. Adapun beberapa peranan dari tanaman lontar yang dapat dimanfaatkan menutut FOX (1996) sebagai berikut

a. Nira atau getah pohon lontar

b. Buah

c. Batang

d. Daun
Metode yang digunakan dealam penelitian ini adalah metode survei. Menurut Nazir (1983) metode survei adalah penyelidikan yang diadakan untuk memperoleh fakta-fakta dari gejala-gejala yang ada dan mencari keterangan-keterangan secara faktual. Menurut Sugiyono metode survei digunakan untuk mendapatkan data dari tempat tertentu yang alamiah dengan cara mengedarkan kuisioner, wawancara terstruktur dan sebagainya. Dalam penelitian ini, metode survei digunakan untuk mengetahui potensi pemanfatan dan nilai ekonomi lontar di Kota Kupang serta akibat dari kegiatan tersebut.

\subsection{Variabel Penelitian}

Berdasarkan permasalahan yang dikemukakan, maka variabel dan indikator dalam penelitian ini adalah seperti pada Tabel 1. dibawah ini:

Tabel 1. Variabel dan Indikator Penelitian

\begin{tabular}{lll}
\hline \multicolumn{1}{c}{ Variabel } & \multicolumn{1}{c}{ Indikator } & \multicolumn{1}{c}{ Keterangan } \\
\hline Pemanfatan lontar & Buah lontar & \\
& Nira lontar & Nilai Jual \\
& Daun lontar & \\
& Batang lontar & a. TEV \\
& 1. Nilai manfaat langsung (direct use) & b. CVM \\
& 2. Nilai manfaat tidak langsung (indirect use) & c. WTP \\
& 3. Nilai pilihan (option value) & \\
& 4. Nilai warisan (Bequest value) & \\
& 5. Nilai keberadaan (xistance value) & \\
\hline
\end{tabular}

\subsection{Jenis dan Metode Penelitian}

Penelitian ini tergolong penelitian deskriptif. Nasir (1983) mengemukakan bahwa penelitian deskriptif mempelajari masalah-masalah dalam masyarakat, serta tata cara yang berlaku dalam masyarakat pada situasi-situasi tertentu 
termasuk tentang hubungan kegiatan-kegiatan, sikap-sikap, pandangan-pandangan serta proses yang sedang berlangsung dan pengaruh-pengaruh dari suatu fenomena.

Metode yang digunakan dealam penelitian ini adalah metode survei. Menurut Nazir (1983) metode survei adalah penyelidikan yang diadakan untuk memperoleh fakta-fakta dari gejala-gejala yang ada dan mencari keterangan-keterangan secara faktual. Menurut Sugiyono metode survei digunakan untuk mendapatkan data dari tempat tertentu yang alamiah dengan cara mengedarkan kuisioner, wawancara terstruktur dan sebagainya. Dalam penelitian ini, metode survei digunakan untuk mengetahui potensi pemanfatan dan nilai ekonomi lontar di Kota Kupang serta akibat dari kegiatan tersebut.

\subsection{Populasi dan Sampel penelitian}

Populasi dan sampel serta teknik sampling yang digunakan dalam penelitian ini dapat dilihat pada Tabel 2 berikut :

Tabel 2. Populasi dan Teknik Sampling Penelitian

\begin{tabular}{llll}
\hline No & \multicolumn{1}{c}{ Populasi } & \multicolumn{1}{c}{ Sampel (n) } & \multicolumn{1}{c}{ Teknik Sampling } \\
\hline 1 & $\begin{array}{l}\text { Pohon Lontar } \\
\text { Masyarakat pemanfaat } \\
\text { lontar }\end{array}$ & Pada daerah sebaran lontar terbanyak & Pembuatan Transek dan Plot \\
& & Random sampling \\
\hline
\end{tabular}

Teknik sampling secara acak, setiap individu dalam populasi memiliki peluang yang sama untuk dijadikan sampel Syarat: anggota populasi dianggap homogen, cara pengambilan sampel bisa melalui undian. Sampling ini memiliki bias terkecil dan generalisasi tinggi. Dalam penentuan jumlah sampel digunakan rumus Slovin yaitu ;

$$
n=\frac{N}{e^{2}}
$$

Keterangan :

$\mathrm{n} \quad=$ Sampel

$\mathrm{N} \quad=$ Populasi (masyarakat pemanfaat lontar)

e $\quad=$ batas toleransi kesalahan $(5 \%=0,05)$

\subsection{Metode Analisis Data}

Pengumpulan data untuk pemanfaatan langsung (Direct use Value), menggunakan metode harga pasar (Market term), sedangkan untuk nilai pilihan (Option Value), Nilai keberadaan (Exsistance Value), dan nilai warisan (Bequest Value) yang termasuk dalam pemanfaatan tidak langsung (Indirect use Value) menggunakan Metode Valuasi Kontingen (Contingent Value method.).
Metode analisa data yang digunakan adalah analisa data deskriptif kualitatif dan Teknik analisa data yang digunakan adalah Contingent Valuation Method (CVM) yaitu teknik survei atau pertanyaan langsung pada sejumlah responden dengan menggunakan kuisioner, berdasarkan pendapat yang nyata dari data bersifat karakteristik untuk mendapatkan manfaat dari nilai jasa lingkungan yang tidak terungkap dapat mendekati harga pasar berdasarkan keinginan membayar individu pemilik atau pengguna.

Pendugaan nilai manfaat ekonomis jasa lingkungan non market dengan keinginan membayar (WTP) individual pemanfaatan lontar berdasarkan pada teknik pengukuran nilai non pasar secara langsung yaitu metode CVM (Contingent Valuation Method) adalah penilaian jasa lingkungan terhadap keberadaan sumber daya alam berdasarkan persepsi masyarakat pengguna, dengan menanyakan kepada responden manfaat yang dihasilkan oleh lontar berupa jasa lingkungan terhadap kelangsungan populasinya dalam upaya konservasi tanaman lontar ke depan melalui keinginan membayar mereka (Willingens to Pay).

Analisis WTP dari masyarakat pemanfaat lontar menggunakan pendekatan CVM, dimana 
tahapan dalam penelitian untuk menentukan nilai WTP untuk jasa lingkungan yang diberikan tanaman lontar meliputi beberapa langkah yaitu :

a. Membuat Pasar Hipotetik

Dalam membuat pasar hipotetik, terlebih dahulu responden diminta untuk mendengarkan pernyataan mengenai pemanfaatan lontar saat ini. Selanjutnya responden diminta mendengarkan suatu pernyataan mengenai nilai ekonomi lontar yang tidak dijual di pasaran. Namun saat ini masyarakat masih belum mengetahui manfaat dan nilai ekonomi lontar yang tidak dijual di pasar, seperti serapan carbon, penyerapan air, dan lain sebagainya, oleh karena itu masyarakat pemilik dan pemanfaat lontar di ajak untuk menjaga kelestarian tanaman lontar. Selanjutnya responden diberi pertanyaan mengenai kesediaannya membayar manfaat lontar yang tidak dijual di pasar dan besarnya yang sanggup dibayarkan.

Alat survey yang digunakan dalam penelitian ini adalah kuesioner yang memberikan deskripsi mengapa seluruh responden seharusnya membayar. Informasi yang diberikan kepada responden meliputi keseluruhan aspek dari pasar hipotetik.

Skenario : Jika tanaman lontar memiliki nilai ekonomi dan mempunyai manfaat yang cukup banyak bagi masyarakat baik itu manfaat langsung maupun manfaat tidak langsung maka perlu diketahui manfaat apa saja dari lontar yang tidak dijual di pasaran sehingga dapat diketahui nilai lain dari lontar itu sendiri yang dapat mempengaruhi kehidupan masyarakat, dan oleh sebab itu masyarakat akan lebih memahami akan pemanfatan dan pembudidayaan harus berjalan seimbang. Dengan demikian masyarakat diharapkan memberi harga total untuk tanaman lontar baik dilihat dari nilai manfaat langsungnya maupun nilai manfaat tidak langsung agar dalam pemanfaatan dan budidayanya berjalan selaras.

Dengan skenario ini maka responden mengetahui gambaran tentang situasi hipotetik mengenai berapa besarnya biaya yang patut diberikan untuk nilai lontar dan akan ditanyakan kepada responden mengenai WTP dalam upaya konservasi lontar. Kepada setiap responden akan ditanyakan apakah mereka setuju (ya) atau menolak (tidak setuju) terhadap pemberian harga terhadap lontar tersebut.

Pertanyaan yang menyangkut skenario: Apabila telah diketahui nilai manfaat tidak langsung dari lontar yang tidak dijual di pasar akan tetapi mempunyai manfaat yang penting (jasa lingkungan) bagi masyarakat, maka kepada responden akan ditanyakan kesediaan memberi harga untuk manfaat tidak langsung dari lontar."Bersedia atau tidak Bapak/Ibu/Saudara/I untuk berpartisipasi dalam menjaga dan membudidayakan lontar sebagai salah satu tanaman yang mempunyai nilai manfaat diantaranya sebagai tanaman pionir, menyerap carbon, menghasilkan oksigen, dan menahan banjir? Berapa besarnya biaya yang anda tawar untuk manfaat lontar seperti itu?".

b. Mendapatkan Penawaran Besarnya Nilai WTP

Penawaran besarnya nilai WTP dilakukan melalui wawancara dengan responden dengan bantuan kuesioner. Nilai WTP ditentukan melalui Metode pertanyaan terbuka (open-ended question) yaitu Metode ini dilakukan dengan menanyakan langsung kepada responden berapa jumlah maksimal uang yang ingin dibayarkan atas manfaat lontar bagi lingkungan.Dalam Penelitian ini, besarnya nilai tawaran yang diajukan kepada responden diberikan berdasarkan kemampuan responden untuk membayar nilai manfaat tidak langsung dari lontar.

\section{c. Konsep Contingent Valuation Method}

Contingent Valuation Method (CVM) merupakan suatu metode yang memungkinkan untuk memperkirakan nilai ekonomi dari suatu komoditi yang tidak diperdagangkan dalam pasar. Contingent Valuation Method menggunakan pendekatan secara langsung yang pada dasarnya menanyakan kepada masyarakat mengenai berapa besar nilai maksimum dari WTP untuk manfaat tambahan sebagai kompensasi untuk jasa-jasa bagi lingkungan yang diberikan oleh pohon lontar.Dalam penelitian akan ditanyakan secara 
langsung kesediaan untuk membayar (WTP) kepada masyarakat pemilik dan pemanfaat lontar yang penekanannya pada standar nilai uang (Hanley and Spash, 1993).

d. Memperkirakan faktor-faktor yang mempengaruhi WTP

Faktor-faktor yang mempengaruhi WTP masyarakat untuk membayar nilai dari pohon lontar dapat dianalisa dengan menggunakan model regresi linear berganda. Model regresi dalam penelitian ini adalah :

Mean WTP $=\beta 0+\beta 1$ UMURi $+\beta 2 \mathrm{PDDKi}+\beta 3 \mathrm{PDPTNi}+\varepsilon i$

Pendugaan kurva penawaran yang dilakukan dalam penelitian ini menggunakan persamaan seperti berikut ini:

meanWTP $=f(U M U R, P D D K, T G G, P D P T N, P L R N, K P, L T S I, \varepsilon i)$

e. Menjumlahkan Data (Agregating Data)

Penjumlahan data merupakan proses

dimana nilai tengah penawaran rata-rata dikonversikan terhadap total populasi yang dimaksud. Setelah menduga nilai tengah WTP maka dapat diduga nilai total WTP dari masyarakat dengan menggunakan rumus:

$$
T W T P=\sum_{i=0}^{n} W T P i\left[\frac{n i}{n}\right] \mathrm{P}
$$

$\begin{array}{ll}\text { dimana: } & \\ \text { TWTP } & =\text { Total WTP }(\text { Rp }) \\ \text { WTPi } & =\text { WTP individu ke-i } \\ \mathrm{P} & =\text { jumlah populasi } \\ \mathrm{ni} & =\text { jumlah sampel ke-i } \\ \mathrm{N} & =\text { jumlah sampel } \\ \mathrm{i} & =\text { Responden WTP }(1,2, \ldots, \mathrm{n})\end{array}$

\section{Hasil dan Pembahasan}

\subsection{Keadaan Lontar di Kota Kupang}

Populasi lontar di Nusa Tenggara Timur belum diketahui jumlahnya secara pasti, akan tetapi dapat diperkirakan jumlahnya berkisar antara $4-6$ juta pohon (Mahayasa, 2007). Dari hasil penilitian diperoleh data khusus pada kecamatan Kelapa Lima dan Maulafa berjumlah 8.202 pohon (Lampiran 2). Dimana umumnya pohon lontar yang ada tersebut produktif dan dapat dimanfaatkan.

Dengan meningkatnya penduduk kota Kupang menjadi 384112 jiwa menyebabkan meningkatnya kebutuhan ekonomi masyarakat. Lontar sebagai salah satu sumber daya alam mampu menjawab kebutuhan ekonomi masyarakat tersebut, dimana masyarakat yang memanfaatkan lontar sebagai salah satu mata pencaharian mampu memenuhi kebutuhan hidupnya setiap hari dan juga dapat membiayai pendidikan anak-anak mereka sampai pada jenjang SI. Akan tetapi belum semua masyarakat pengguna lontar memanfaatkan lontar secara maksimal, dari hasil penelitian ini masyarakat dalam pemanfaatan lontar masih sebatas pada apa yang mudah dikerjakan dan cepat mendapatkan uang, sehingga pemanfaatannya masih sebatas untuk pembuatan minuman seperti "laru", pada dasarnya masyarakat paham dan mengerti akan manfaat lontar yang dapat diolah menjadi berbagai macam olahan seperti pembuatan bahan makanan, minuman (sirup) dan juga anyaman bahkan dimanfaatkan sebagai salah satu energi terbarukan (pembuatan bioetanol) akan tetapi masyarakat masih mengalami kendala dalam hal pemasarannya dan juga proses pengolahannya (bioetanol) serta membutuhkan pendampingan, sehingga mereka sampai saat ini memanfaat lontar 
untuk olahan yang mudah dan cepat menghasilkan uang.

\subsection{Sebaran Lontar}

Sebaran lontar yang terbanyak untuk saat ini pada lokasi penelitian yang berada dikawasan kelapa lima (kel. Oesapa dan Kel. Lasiana) dan kecamatan Maulafa,tersebar pada beberapa kelurahan yaitu Kelurahan Oesapa (2150 Pohon), Kelurahan Lasiana (1606 Pohon), Kelurahan Naimata (1162 Pohon), Kelurahan Maulafa (1721 Pohon) (Lampiran 2), akan tetapi dengan jumlah yang banyak ini belum semua pohon lontar dimanfaatkan secara maksimal, hal ini disebabkan karena keterbatasan tenaga kerja, selain itu juga dibutuhkan ketrampilan khusus mulai dari memanjat sampai pada pengolahan lontar menjadi suatu hasil yang dapat dimanfaatkan dan hal inilah yang menyebabkan pemanfaatan lontar belum maksimal meskipun jumlah dan potensi lontar di Kota Kupang terbilang cukup tinggi.

\subsection{Kerapatan Lontar}

Lontar dengan kemampuan beradaptasi yang sangat tinggi dapat ditemui hidup menyebar hampir di seluruh wilayah NTT khususnya Kota Kupang akan tetapi ada tempat-tempat tertentu yang manjadi tempat penyebaran terbanyak dari pohon lontar seperti dari data hasil penelitian di dua kecamatan ini ditemukan lima titik yang merupakan sebaran terbanyak dari pohon lontar (kel. Lasiana, Kel. Oesapa, Kel. Penfui, Kel.Naimata, Kel Maulafa).

Dari hasil penelitian untuk mengetahui kerapatan populasi lontar pada suatu daerah maka dibuat garis transek. Pembuatan garis transek pada dasarnya untuk analisis vegetasi pada suatu wilayah (Soerianegara,1988). Menurut Oosting (1956), menyatakan bahwa transek merupakan garis sampling yang ditarik menyilang pada sebuah bentukan atau beberapa bentukan.Transek yang dibuat pada lokasi penelitian adalah line transek sepanjang $200 \mathrm{~m}$ kemudian dibuat plot sebesar 20 × $20 \mathrm{~m}$ sebanyak 5 plot dengan jarak masing-masing plot $20 \mathrm{~m}$. Untuk menghitung jenis tanaman dewasa. Dari pembuatan plot dan transek ini diperoleh data kerapatan untuk masing- masing wilayah/lokasi pembuatan transek seperti terlihat pada Tabel 3 di bawah ini.

Tabel 3. Kerapatan pohon lontar

\begin{tabular}{clcc}
\hline No & Wilayah/Kelurahan & Densitas & Densitas Relatif (\%) \\
\hline 1 & Lasiana & 0,045 & $100 \%$ \\
2 & Oesapa & 0,05 & $100 \%$ \\
3 & Penfui & 0,0475 & $100 \%$ \\
4 & Naimata & 0,0445 & $100 \%$ \\
5 & Maulafa & 0,0520 & $100 \%$ \\
\hline
\end{tabular}

Sumber. hasil olahan data primer (2016)

Dari Tabel 3 di atas hasil perhitungan kerapatan (density) pohon lontar tertinggi ada pada wilayah kelurahan maulafa. Hal ini menggambarkan bahwa pada wilayah maulafa, pohon lontar masih terdapat dalam jumlah yang banyak pada titik sebaran tertentu dikarenakan pada wilayah ini masih belum banyak kegiatan pembangunan yang dilakukan sehingga pohon lontar masih dapat tumbuh dengan baik.

\subsection{Pemanfaatan dan Ekonomi Lontar}

Keberadaan lontar secara umum pada kecamatan Kelapa Lima dan Kecamatan Maulafa memberikan manfaat yang besar bagi masyarakat. Fox (1996) menyatakan bahwa secara keseluruhan lontar dapat dimanfaatkan sebagai kayu bakar, daun sebagai bahan pembuat anyaman maupun atap rumah, nira dapat di olah menjadi gula cair, gula lempeng, minuman beralkohol maupun dapat diminum secara langsung sedangkan buahnya 
dapat dimakan secara langsung (buah muda) ataupu dapat di olah menjadi bahan makanan yang lain.

Bentuk pendekatan dalam melihat ekonomi lontar pada pembahasan ini yaitu dengan melakukan valuasi ekonomi untuk mendapatkan nilai ekonomi total (TEV). Nilai ekonomi total pohon lontar meliputi 5 (lima ) kategori yaitu ; (1) Nilai manfaat langsung atau direct use value (DUV), (2) Nilai manfaat tidak langsung atau indirect use value (IUV), (3) Nilai manfaat pilihan atau option value (OV), (4) Nilai manfaat keberadaan atau existance value (EV) dan (5) Nilai warisan atau bequest value (BV).

a. Manfaat Langsung

Berdasarkan hasil penelitian terhadap manfaat pohon lontar di kecamatan Kelapa Lima dan Maulafa saat ini ada terdapat beberapa bentuk pemanfaatan yang dilakukan oleh masyarakat.

Daun lontar

Daun lontar merupakan produk yang dipergunakan oleh penduduk yang memanfaatkan terutama para wanita, oleh karena kebanyakan dari masyarakat ini yang memiliki keahlian dan ketrampilan dalam memanfaatkan lontar adalah para wanita. Kebanyakan produk yang dihasilkan yaitu berupa :Wadah air yang dibuat dari daun lontar ini biasanya digunakan sebagai tempat untuk menaruh air nira lontar dan juga sebagai gayung untuk menakar/mengukur air nira hasil sadapan dimana daun yang digunakan daun muda yang kemudian dikeringkan. Dari hasil penelitian (wawancara) yang menggunakan daun lontar sebagai wadah air ada 6 orang. Dalam sehari satu orang menyadap sebanyak 2 kali dan membutuhkan wadah air sebanyak 2 buah untuk menampung air nira hasil sadapannya, sehingga dalam sebulan mereka menggunakan wadah air adalah : 2 wadah x 4 minggu x 6 orang $=48$ wadah air. Berdasarkan data diatas maka hasil perhitungan manfaat dari daun lontar sebagai wadah air dapat dilihat pada Tabel 4 berikut :

Tabel 4. Penggunaan Wadah Air

\begin{tabular}{cccccc}
\hline No & Jenis/Manfaat & Hasil/Bulan & Hasil/Tahun & Harga & Jumlah Harga \\
\hline 1 & Wadah air & 48 & 576 & 30.000 & 17.280000 \\
\hline
\end{tabular}

Sumber. hasil olahan data primer (2016)

Daun lontar juga dapat dimanfaatkan dan dibuat menjadi keranjang, selain itu daun lontar juga dapat digunakan dalam pembuatan topi, kertas rokok, dan lain sebagainya, Fox (1996). Keranjang yang dibuat oleh masyarakat yang ada pada lokasi penelitian belum mendapatkan tempat di pasaran untuk diperdagangkan, sampai saat ini hasil pembuatan (anyaman) keranjang masih terbatas pada pemesanan, jika tidak ada pemesanan maka tidak ada hasil anyaman keranjang yang dibuat. Selain keranjang ada juga anyaman yang dibuat sebagai pengganti piring yang di buat dan dijual di tempat wisata sebagai tempat untuk menikmati makanan khas kupang seperti "pisang gepe". Rekapitulasi anyaman keranjang dan tempat makan dapat dilihat pada Tabel 5 berikut. 
Jurnal Bumi Lestari, Volume 16 No. 2, Agustus 2016, hlm. 139-154

Tabel 5. Penggunaan untuk keranjang dan wadah makanan

\begin{tabular}{cccccc}
\hline No & Jenis Manfaat & Hasil/Bulan & Hasil/Tahun & Harga & Jumlah Harga \\
\hline 1 & Keranjang & 4 & 48 & 30000 & 1440000 \\
2 & Tempat makan & 20 & 200 & 5000 & 1000000 \\
& Jumlah & & & & 2440000 \\
\hline
\end{tabular}

Sumber. hasil olahan data primer (2016)

Daun lontar juga oleh beberapa orang (masyarakat pemanfaat lontar) digunakan dalam pembuatan atap rumah ("lak") sebagai tempat pemasakan/pembuatan gula lempeng/gula cair. Rata-rata jumlah daun yang di gunakan untuk pembuatan 1 rumah (lak) sebanyak 1000 lembar dengan total harga Rp.2000 000 (@. Rp 2000).

Tulang daun lontar

Sapu yang dibuat dari tulang daun lontar masih di lakukan oleh beberapa orang untuk keperluan sendiri dan tidak di perjualbelikan. Diasumsikan hrga sesuai harga jual maka sapu yang di hasilakan 1 ikat hrga jualnya adalah Rp.5000 maka 1 bulannya rata-rata sapu yang dihasilkan adalah 2 buah maka harga yang dihasilkan dalam 1 bulan adalah 2 X Rp.5000 = Rp. 10.000, maka dala 1 tahun dapat menghasilkan Rp.10.000 X $12=$ Rp.120 000.

\section{Bunga lontar}

Dari hasil penelitian bunga lontar masih dominan dalam pemanfaatannya oleh masyarakat untuk pembuatan hasil olahan diantaranya untuk pembuatan gula lempeng, gula cair, dan juga minuman (laru) yang masih memiliki nilai jual yang cukup tinggi, yang mana dalam 1 pohon menghasilkan 1- 2 liter nira lontar dalam 1 kali penyadapan (sehari dilakukan 2 kali penyadapan).

Dalam satu pohon lontar biasanya (ratarata) terdapat 5 rangkai bunga/mayang dimana dalam proses penyadapannya ada yang di ikat menjadi 1 ikatan ataupun dipisah kemudian di sadap. Menurut Fox (1996) sebatang pohon lontar dengan 5 mayang dapatmenghasilkan nira 6,7 liter per hari sedangkan pohon dengan 1 mayang dapatmenghasilkan nira 2,25 liter per hari.

Gula lempeng memiliki nilai jual yang cukup tinggi dan masih banyak masyarakat yang membutuhkannya oleh sebab itu pembuatan gula lempeng ini masih terus dilaksanakan oleh masyarakat untuk pemenuhan permintaan pasar. Pembuatan gula lempeng ini pada lokasi penelitian tidak dilakukan oleh semua masyarakat yang menyadap nira lontar tersebut, karena masyarakat lainnya melihat dalam proses pembuatannya memakan waktu yang cukup lama dan membutuhkan biaya tambahan seperti pengadaan kayu bakar serta periuk untuk memasaknya, dari 5 titik sampel penelitian ditemukan ada 2 titik lokasi yang ditemukan hasil dari penyadapan nira lontar tersebut di buat menjadi gula lempeng, yaitu pada lokasi di Oesapa dan Lasiana (6 Orang).

Hasil penelitian ini juga menunjukan dalam sekali pembuatan gula lempeng nira yang digunakan tidak menentu tergantung banyaknya nira yang di peroleh saat itu, hasil nira lontar yang paling banyak biasanya pada musim kemarau (september-oktober). Untuk saat ini rata-rata nira lontar yang dihasilkan sebanyak 50 liter yang dihasilkan dari 30 pohon ( 1 kali penyadapan, dalam sehari dilakukan 2 kali penyadapan) berarti rata-rata tiap pohon menghasilkan nira sebanyak 1,7 liter.

Dalam pembuatan gula lempeng ini dari 50 liter nira menghasilkan sebanyak $7 \mathrm{Kg}$ gula lempeng dimana $1 \mathrm{Kg}$ berisi 14 buah lempeng gula, ini dapat dianalisis bahwa $7 \mathrm{Kg}$ x 14 lempeng 
= 98 lempeng gula, dengan harga per $1 \mathrm{Kg}$ gula lempeng adalah Rp.25 000 berarti dalam 1 kali proses pembuatan gula lempeng akan menghasilkan uang sebesar Rp. 175.000 (Rp.25.000 x 7 Kg). Jika diasumsikan dalam 2 kali penyadapan menghasilkan 100 liter berarti gula yang dihasilkan sebesar $14 \mathrm{Kg}$ dengan 196 lempeng maka akan menghasilkan uang sebesar Rp. 350.000 dalam 1 hari, 1 bulan menghasilkan Rp.10.500.000 (Rp.350 000 X 30) dan 1 tahun penghasilan dari gula lempeng mencapai Rp. 126 000000 .

Berdasarkan hasil penelitian tidak ditemukan pemanfaatan nira lontar dalam pembuatan gula cair secara rutin. Pembuatan gula cair dibuat hanya jika ada pemesanan dimana apabila ada permintaan akan gula cair maka nira yang dihasilkan akan dubuat menjadi gula cair dengan harga jual Rp. 200.000/5 liter.5 liter gula cair dihasilkan dari 20 liter nira (4 liter nira menghasilakn 1 liter gula cair). Apabila diasumsikan dalam 1 bulan dihasilkan 5 liter gula cair maka dalam 1 tahun bisa menghasilkan 60 liter dengan harga 60 ltr X Rp.200 $000=\mathrm{Rp}$ 12000000.Dalam pembatan gula lempeng membutuhkan waktu yang lebih lama $( \pm 2$ jam $)$ dibandingkan dengan dengan gula cair $(( \pm 1-1,5$ jam). Yang mana bahan bakar (kayu bakar) yang dibeli digunakan dalam waktu 2 hari.

Pemanfaatan nira lontar untuk pembuatan minuman tuak/laru merupakan pekerjaan yang mudah dan tidak membutuhkan biaya tambahan yang banyak, karena yang diandalkan hanyalah kekuatan tenaga untuk memanjat pohon lontar karena hasil nira yang diperoleh langsung bisa dijual/dimanfaatkan tanpa menunggu proses yang panjang.

Pembuatan laru tidak ada pada semua titik yang menjadi sampel penelitan tetapi hanya pada beberapa titik dari lokasi penelitian dan dari jumlah responden yang menjadi sampel penelitian sebanyak 23 orang ada 15 orang yang memproduksi minuman laru karena dianggap dalam pengolahannya tidak terlalu repot dan juga tidak memakan waktu lama dan yang utama cepat mendapatkan uang.

Harga untuk laru rata-ratanya dijual per liter Rp.5000 dan harga borongnya per 5 liter adalah Rp.20.000, dalam sehari (1 kali penyadapan) ratarata laru yang dihasilkan adalah 20 liter (17 pohon) sehingga jika dihitung dari satu kali penyadapan dengan harga jual per liter maka diperoleh hasil sebesar 20 L x Rp. 5000 = Rp. 100 000/hari (1 kali penyadapan), dalam 1 bulan memperoleh hasil sebesar Rp.100.000 x 30 hari = Rp. 3000.000 berarti dalam 1 tahun memperoleh hasil sebesar Rp.36 000000 (Rp.3000 000 x 12) dan dikurangi biaya sewa pohon lontar sebesar Rp.7000 000/tahun, maka diperoleh hasil bersih dalam setahun adalah Rp.36 000000 - Rp. $7000000=$ Rp. 2.900 000. Apabila dijual dengan harga borong maka Rp.20.000 x 4 (20 liter : 5 liter) = Rp.80.000/hari (1 kali penyadapan). sehingga jika dilihat dari hasilnya yang lebih menguntungkan adalah jika dijual per liter.

Harga borongan Biasanya dijual kepada "langganan" yang mengambil "laru" secara konstan untuk dijual kembali atau dengan istilah "diover" dan akan dijual lagi dengan harga per 1 liter $=$ Rp. 7000 dan per 5 liter $=$ Rp. 25 000. Bagi masyarakat yang "over" minuman ini dari hasil penjualan yang diperoleh mereka harus membayar uang sewa tempat berjualan sebesar Rp. 25.000/bulan (Rp. 570.000/Tahun), biaya ojek Rp. 5000/hari, botol aqua (ukuran 1,5 L) 3 buah dengan harga Rp. @. Rp.500 (1 bulan Rp.45.000 dan 1 tahun = Rp.540.000), yang mana dalam 1 hari rata-rata mereka menjual sebanyak 15 liter (jual per liter, $1 \mathrm{~L}=\mathrm{Rp}$.7000) sehingga hasil yang diperoleh dalam 1 hari adalah sebesar $15 \mathrm{~L} \mathrm{x}$ Rp.7000 = Rp.105 000 dan dalam sebulan penghasilan sebesar Rp. $3.150 \quad 000$ apabila dikurangi dengan biaya sewa tempat dan pembelian botol maka diperoleh penghasilan bersih sebesar Rp. 2040000 (Rp.3.150 000 Rp.570.000 - Rp. 540.000).

Buah lontar

Buah lontar pada umumnya tidak begitu banyak yang memanfaatkan untuk dijual, hanya 
beberapa orang saja memanfaatkan buah lontar terutama yang muda untuk dijual. Buah lontar yang masih muda memiliki isi yang terbungkus oleh tempurungnya dan juga oleh serabut buahnya, isi dari buah lontar dapat dimakan langsung dan memiliki rasa seperti buah kelapa muda. Dalam 1 pohon lontar terdapat 4 tandan buah dengan masing-masing tandan memiliki 12 buah, sehingga bila dihitung 1 pohon lontar memiliki 144 isi buah lontar. $(4 \times 12 \times 3)$. harga 5 isi buah lontar adalah Rp.5000/buah, jadi dalam 1 pohon lontar dapat menghasilkan $144: 5$ x Rp. $5000=$ Rp. 144 000, hal ini dilakukan selama 2 kali panen dalam setahun, sehingga dalam 1 tahun menghasilkan sebesar Rp. 288 000, sedangkan untuk buah yang sudah tua pada lokasi penelitian tidak ditemukan bentuk pengolahannya lebih lanjut tapi dibiarkan begitu saja dan dijadikan sebagai makanan ternak.
Pelepah lontar

Pelepah lontar oleh beberapa orang diambil untuk dibuat dinding rumah (dapur), akan tetapi bagi masyarakat lainnya terutama yang membuat gula cair/gula lempeng memanfaatkannya sebagai bahan bakar.

Hasil penelitian Asrial (2008) menyatakan bahwa dalam 1 pohon lontar menghasilkan 36 pelepah dalam 1 tahun, sehingga jika diasumsikan 1 ikat kayu bakar sama dengan 3 pelepah maka bisa menghemat 9 ikat kayu bakar yang harga/ikatnya adalah Rp. 5000 maka dapat menghasilkan 9 x Rp. Rp.5000 = Rp.45.000 sehingga dari 1 pohon lontar dalam setahun bisa membantu menghemat pembelian kayu bakar sebesar Rp.45.000. Jadi secara keseluruhan nilai manfaat langsung dari pohon lontar untuk lebih lengkapnya dapat dilihat pada Tabel 6 berikut:

Tabel 6. Nilai manfaat langsung

\begin{tabular}{llcc}
\hline \multicolumn{1}{c}{ Manfaat Langsung } & Nilai /Tahun & Total \\
\hline $\mathrm{a}$ & Daun Lontar & 17280000 & 21720000 \\
& Wadah air & 1440000 & \\
& Keranjang & 1000000 & \\
& Anyaman tempat makan & 2000000 & 120000 \\
& Atap rumah & 120000 & \\
\hline $\mathrm{b}$ & Tulang daun lontar & 174000000 \\
& Sapu & 12000000 & \\
\hline $\mathrm{c}$ & Bunga lontar & 360000000000 & \\
& Gula cair & 288000 & 288000 \\
& Gula lempeng & & \\
& Minuman (Laru) (eceran) & 45000 & 176626000 \\
\hline $\mathrm{d}$ & Buah lontar & & \\
\hline $\mathrm{e}$ & Kayu lontar & & \\
& Kayu bakar & & \\
& Harga total & & \\
\hline
\end{tabular}

Sumber. hasil olahan data primer (2016)

b. Manfaat Tidak Langsung

Pohon lontar secara tidak langsung mempunyai manfaat lain bagi lingkungannya salah satunya peranannya adalah sebagai serapan karbon, yang mana dari hasil penelitian Balai
Penelitian Kehutanan Kupang (2014), mengatakan bahwa pohon lontar yang memiliki diameter $30 \mathrm{~cm}$ mampu menyimpan karbon sebesar 73,50 ton/ha.

Manfaat tidak langsung adalah nilai jasa yang ditimbulkan dengan adanya pohon lontar 
pada daerah penelitian yang apabila nilainya di adopsi dari perhitungan NRM (Natural Resources Management) yang berdasarkan metodenya manfaat tidak langsung dari lontar adalah sebagai serapan karbon yang dinilai berdasarkan hutan primer sebesar (U\$ 5.00/ha/Thn), harga 1 U\$\$ pada bulan mei Rp. 13.640 (per 21 mei 2016), sedangkan luas kecamatan maulafa dan kelapa lima pada lokasi sebaran terbanyak lontar/luas wilayah pada pembuatan transek adalah 10 ha sehingga nilai manfaat tidak langsung 10 ha $\mathrm{x} 13$ 640 x 5 = Rp. 682 000/Tahun.

\section{c. Manfaat Pilihan}

Manfaat pilihan merupakan pilihan dari para pemilik pohon lontar yang mana dari hasil wawancara yang sudah dilakukan manfaat pilihan dari pohon lontar tidak ada.

\section{d. Manfaaat Keberadaan}

Manfaat keberadaan dari pohon lontar cukup mempunyai peranan yang penting bagi segala makhluk hidup yang memanfaatkannya dimana dengan keberaadaan pohon lontar menambah nilai keanekaragaman yang mana merupakan nilai jasa yang penting dan apabila perhitungannya diadopsi dari perhitungan NRM (Natural Resources Management) dimana pohon lontar mempunyai manfaat sebagai tempat lebah dan burung bersarang, dan melestarikan keanekaragaman hayati yang dinilai berdasarkan luas hutan primer sebesar (U\$ 9.45/Ha/Thn), harga 1 U\$\$ pada bulan mei Rp. 13.640 (per 21 mei 2016), sedangkan luas kecamatan maulafa dan kelapa lima pada lokasi sebaran terbanyak lontar/luas wilayah pada pembuatan transek adalah 10 ha sehingga nilai manfaat tidak langsung 10 ha x 13640 × 9,45=Rp.1288980/Tahun.

e. Manfaat Warisan

Manfaat warisan, dari hasil wawancara responden tidak memberikan angka yang pasti tentang warisan hal ini disebabkan karena pohon lontar yang ada saat ini bukanlah milik pribadi tetapi hanya bersifat menyewa dari pemilik aslinya, sementara bagi pemilik lontar apa bila lahan yang ditumbuhi lontar suatu waktu ada yang mau membeli maka akan di jual, responden juga mengatakan bhwa pohon lontar masih bisa tetap tumbuh dan berkembang terus dan bisa dilestarikan sampai anak cucu asalkan tidak ditebang habis untuk kegiatan pembangunan.

Tabel 7. Nilai Total Ekonomi Lontar

\begin{tabular}{lcc}
\hline \multicolumn{1}{c}{ Jenis Manfaat } & $\begin{array}{c}\text { Nilai Manfaat } \\
(\mathrm{Rp}) / \text { Tahun }\end{array}$ & $\begin{array}{c}\text { Jumlah/Manfaat } \\
(\mathrm{Rp}) / 5 \text { tahun }\end{array}$ \\
\hline Manfaat Langsung & 176626000 & 883130000 \\
Manfaat Tak Langsung & 682000 & 3410000 \\
Manfaat Pilihan & 0 & 0 \\
Manfaat Keberadaan & 1288980 & 6444900 \\
Manfaat Warisan & 0 & 0 \\
\hline \multicolumn{1}{c}{ Nilai Total } & 178596980 & 892984900
\end{tabular}

Sumber. hasil olahan data primer (2016)

f. WTP

Kesediaan membayar oleh masayarakat akan peranan pohon lontar bagi kehidupan, secara umum responden memberikan harga yang bervariasi seperti yang terlihat dari Tabel 8 di bawah ini. 
Tabel 8. Analisis nilai WTP

\begin{tabular}{llc}
\hline No & \multicolumn{1}{c}{ Indikator pemanfaatan } & $\begin{array}{c}\text { Jumlah Kesediaan membayar (Rp) responden (4 } \\
\text { pohon) }\end{array}$ \\
\hline 1 & Tanaman Pionir & 3085000 \\
2 & Tanaman peneduh & 4615000 \\
3 & Serapan karbon & 3555000 \\
4 & Penahan Banjir & 2800000 \\
\hline
\end{tabular}

Sumber. hasil olahan data primer (2016)

Tabel 9. Rata-rata nilai (Rp) yang diberikan untuk jasa lingkungan dari lontar

\begin{tabular}{|c|c|c|c|c|}
\hline \multirow{2}{*}{$\begin{array}{l}\text { JUMLAH } \\
\text { POHON }\end{array}$} & \multicolumn{4}{|c|}{ JASA-JASA LINGKUNGAN DAN HARGA YANG DIBERIKAN } \\
\hline & $\begin{array}{c}\text { Tanaman } \\
\text { pionir }\end{array}$ & $\begin{array}{l}\text { Tanaman } \\
\text { Peneduh }\end{array}$ & $\begin{array}{c}\text { Serapan } \\
\text { Carbon }\end{array}$ & Penahan Banjir \\
\hline 1 & 13235 & 22059 & 22059 & 17647 \\
\hline 2 & 8824 & 17645 & 15441 & 6618 \\
\hline 3 & 4412 & 15441 & 6618 & 2206 \\
\hline 4 & 2206 & 8824 & 2206 & 1324 \\
\hline RATA-RATA & 7169 & 15992 & 11581 & 6949 \\
\hline
\end{tabular}

Sumber. hasil olahan data primer (2016)

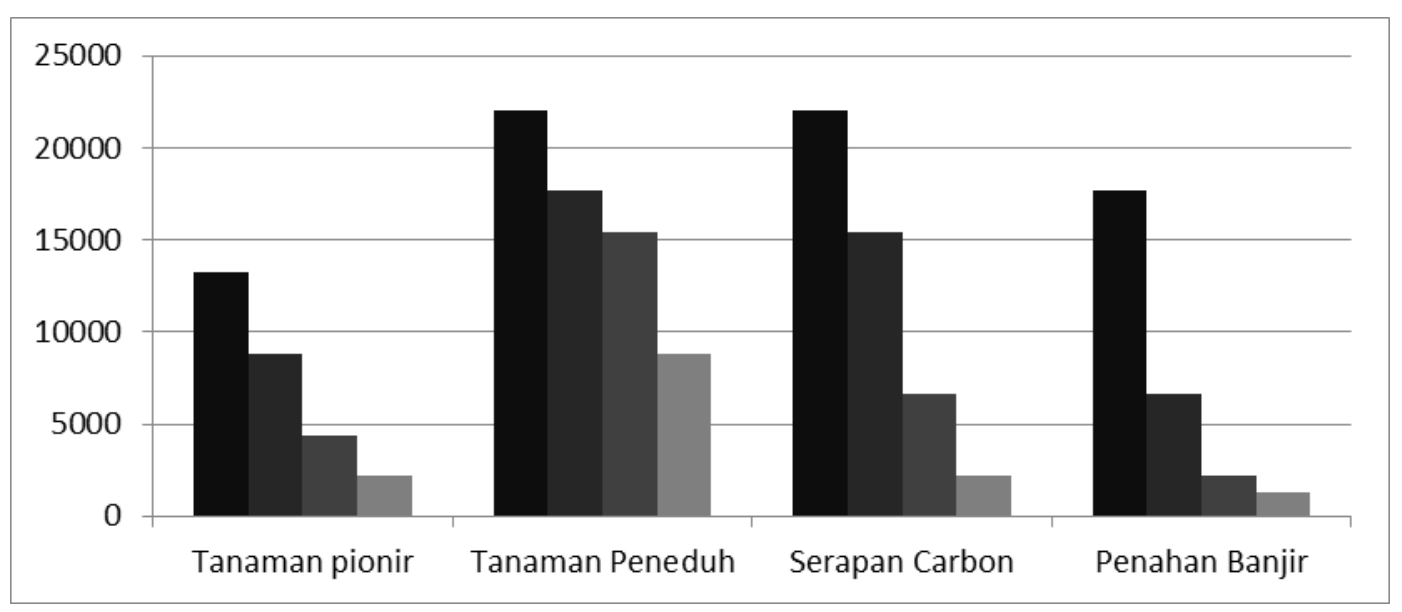

Gambar 1. Grafik Jumlah pohon, jasa lingkungan dan nilai WTP

Berdasarkan Tabel 9 dan Gambar 1 diatas terlihat bahwa kesediaan membayar dari masyarakat untuk jasa lingkungan non market yang diberikan lontar berbeda antara satu dengan yang lain, dimana dari beberapa (4) jumlah pohon yang ditawarkan masyarakat memberikan nilai yang berbeda pula untuk masing-masingnya, semakin banyak jumlah pohon yang ditawarkan kepada masyarakat, semakin kecil nilai yang diberikan hal ini disebabkan oleh karena masyarakat pemanafaat lontar tidak terlalu memperdulikan manfaat lontar untuk jasa lingkungan yang diberikan, disebabkan masyarakat kurang memperdulikan manfaat lain dari pohon 
lontar oleh karena pohon lontar yang dimanfaatkan bukan merupakan hak milik dari para petani penyadap lontar tersebut akan tetapi dari grafik dan juga tabel diatas masih terlihat angka yang diberikan bagi jasa lingkungan pohon lontar sebagai peneduh dan juga serapan karbon yang cukup tinggi.

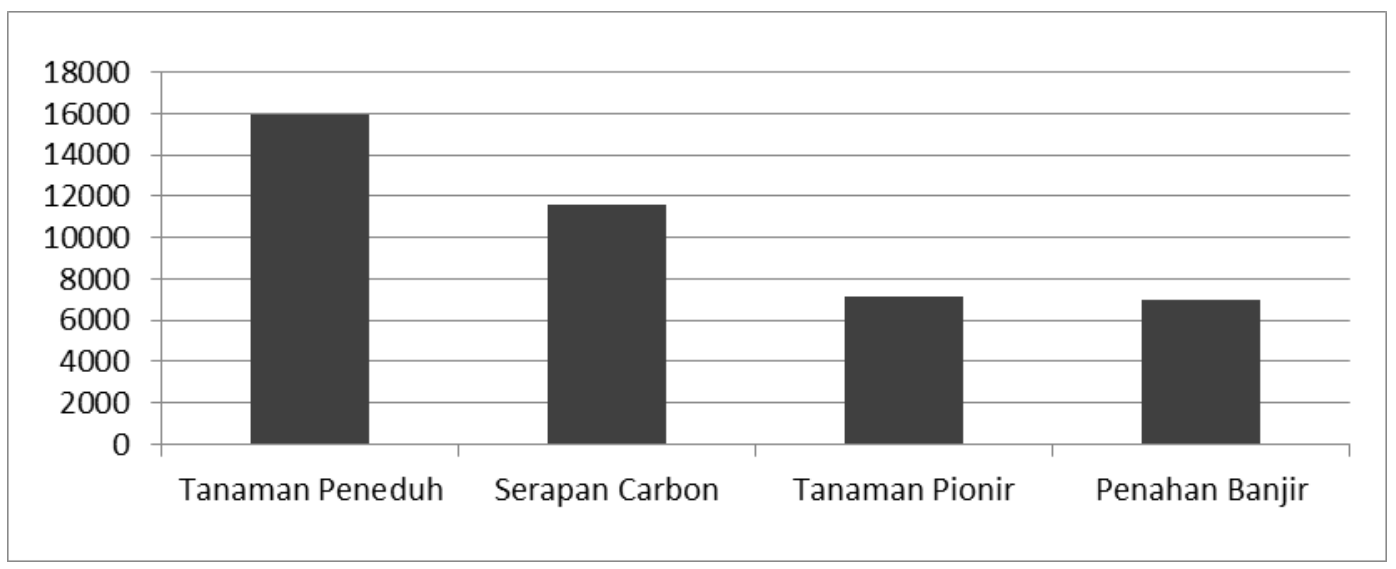

Gambar 2. Grafik Jumlah rata-rata kesedian membayar jasa lingkungan tanaman lontar

Kurva WTP responden dibentuk tersebut.Nilai WTP menunjukkan harga dari jasaberdasarkan nilai WTP responden terhadap jasa jasa lingkungan non market dari pohon lontar lingkungan pohon lontar. Kurva WTP ini tersebut. Berdasarkan jawaban yang diperoleh dari menggambarkan hubungan tingkat WTP yang responden, maka nilai WTP dapat dijelaskan pada bersedia dibayarkan dengan jumlah responden tabel 19, sedangkan kurva tawaran WTP yang yang bersedia membayar pada tingkat WTP dihasilkan dapat dilihat pada Gambar 3.

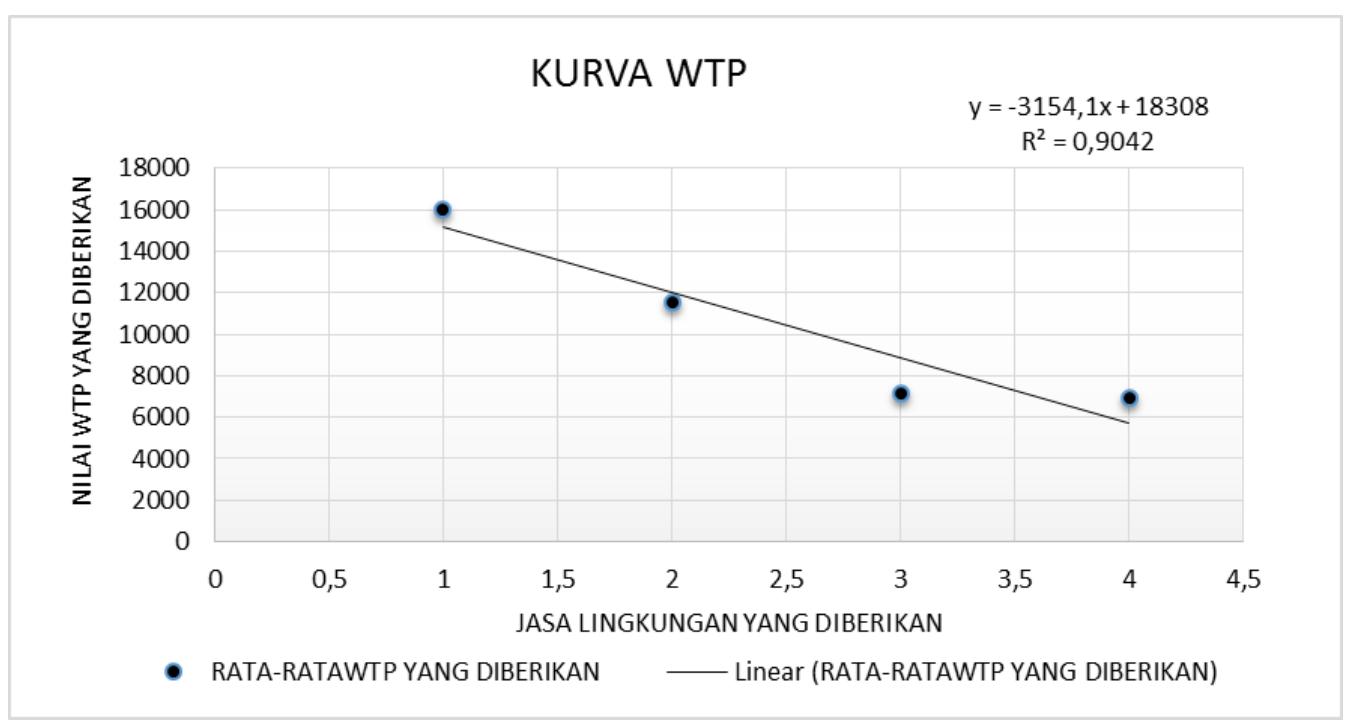

Gambar 3. Kurva Tawaran WTP 
Berdasarkan hasil penelitian ini peneliti juga ingin melihat apakah ada pengaruh dari faktor-faktor seperti umur, tingkat pendidikan, dan juga pendapatan terhadap kesedian membayar masyarakat (WTP) untuk jasa lingkungan non market dari pohon lontar dengan melakukan pengujian statistik.

Hasil analisis menunjukan bahwa faktor umur dan pendapatan tidak berpengaruh nyata terhadap sedangkan pendidikan berpengaruh nyata terhadap terhadap kesediaan membayar (WTP) untuk jasa lingkungan non market dari pohon lontar, ini menunjukan bahwa masyarakat berdasarkan tingkat pendidikannya sudah memahami akan manfaat lain yang diberikan (jasa non market) pohon lontar, hal ini dibuktikan dengan hasil uji statistik seperti pada Tabel $10 \mathrm{di}$ bawah ini :

Tabel 10. Model Summary

\begin{tabular}{lcccccc}
\hline & Coefficients & $\begin{array}{c}\text { Standard } \\
\text { Error }\end{array}$ & $t$ Stat & P-value & Lower 95\% & Upper 95\% \\
\hline Intercept & 110601,62 & 129164,39 & 0,8562857 & 0,3986279 & $-153187,25$ & 374390,49 \\
UMUR & 2876,3222 & 2502,5097 & 1,1493751 & 0,2594825 & $-2234,4843$ & 7987,1288 \\
PENDIDIKAN & 34255,38 & 16545,596 & 2,0703625 & 0,0471207 & 464,76585 & 68045,994 \\
& & & & & & \\
PENDAPATAN & 0,1339785 & 0,0822727 & 1,6284683 & 0,1138837 & $-0,0340448$ & 0,3020019 \\
\hline
\end{tabular}

Tabel diatas menunjukan dari 3 variabel independen $(\mathrm{X} 1, \quad \mathrm{X} 2, \quad \mathrm{X} 3 \quad /$ umur,pendidikan,pendapatan) dua (2) variabel tidak berpengaruh terhadap variabel dependen (Y/WTP) sedangkan satu (1) Variabel yaitu pendidikan berpengaruh nyata terhadap kesdiaan membayar untuk jasa lingkungan non market pohon lontar. Dari hasil pada data tersebut juga menunjukan tingkat pengetahuan responden akan manfaat dari tanaman lontar untuk jasa lingkungan non market tersebut.

\section{g. Total WTP}

Dari data responden dengan kesediaan membayar WTP untuk jasa lingkungan yang diberikan dengan menghitung total keseluruhan kesediaan membayar jasa lingkungan non market adalah sebesar Rp. 477.870000.

\subsection{Pelestarian Lontar}

Masyarakat Kota Kupang terutama mereka yang menggantungkan hidupnya dengan memanfatkan pohon lontar sebagai mata pencaharian untuk pemenuhan ekonominya, dari hasil penelitian (wawancara) melihat tanaman ini sebagai salah satu tanaman yang menguntungkan dengan berbagai macam manfaat yang dapat di gunakan untuk kelangsungan hidupnya, akan tetapi yang menjadi kendalanya adalah masyarakat yang memanfaatkan pohon lontar sampai saat ini masih belum menunjukan upaya untuk melestarikan ataupun membudidayakan tanaman tersebut karena masyarakat berpendapat bahwa tanaman lontar ini dapat dengan mudah tumbuh tanpa harus dibudidayakan (ditanam) selain itu masyarakat yang memanfaatkan tanaman lontar tersebut merupakan pendatang pada umumnya, yang mana tanaman lontar yang dimanfaatkan tersebut bukan milik pribadi mereka melainkan milik orang lain yang disewakan kepada mereka untuk dimanfaatkan dan apabila suatu saat nanti lahan yang ditumbuhi tanaman lontar tersebut di jual oleh pemiliknya maka dengan sendirinya masyarakat pemanfaat lontar tidak bisa memanfaatkannya lagi.

Lontar sebagai salah satu tanaman khas Nusa Tenggara Timur yang mana telah diketahui manfaat yang diberikan baik secara langsung maupun tidak langsung sangat besar bagi 
masyarakat pengguna dan sekitarnya ternyata belum mendapat perhatian secara intensif untuk upaya pelestariannya. Dari hasil wawancara dengan responden diketahui bahwa sampai saat dilakukan penelitian belum ada pendataan populasi, sosialisai ataupun pendampingan bagi masyarakat sehubungan dengan teknik-teknik dalam upaya pelestarian tanaman lontar tersebut, yang ada baru sebatas himbauan untuk mempertahankan keberadaan tanaman lontar tersebut.

Kegiatan-kegiatan yang diberikan oleh pemerintah maupun dinas tekait hanya terbatas pada proses pengolahan hasil lontar dan juga pembuatan anyaman. Untuk proses pengolahan hasil (nira, buah) lontar pernah diadakan dan diberikan pendampingan tapi tidak berjalan lama yang akhirnya tidak berlanjut lagi dan masyarakat kembali memanfaatkan hasil lontar untuk di olah sebagaimana yang mereka ketahui dan yang biasa meraka lakukan.

\section{Simpulan}

Simpulan yang dapat diambil dari hasil penelitian ini berhubungan dengan masalah yang diangkat dan tujuan yang ingin dicapai yaitu :

Pemanfaatan lontar pada lokasi penelitian dapat dikatakan belum maksimal jika dibandingkan dengan kegunaan lontar yang begitu banyak, ini ditunjukan dari hasil penelitian yang mana lontar hanya dimanfaatkan dalam pembuatan beberapa olahan seperti pembuatan gula lempeng, gula cair dan minuman (Laru), pada umumnya masyarakat lebih memilih pengolahan lontar dalam pembuatan minuman (laru) karena dianggap lebih mudah dan cepat dalam menghasilkan uang, sehingga belum ada bentuk pemanfaatan lontar yang lain yang dapat di olah masyarakat.

Berdasarkan nilai valuasi ekonomi lontar (Tabel 17.) menunjukan bahwa 1 pohon lontar memiliki nilai ekonomi yang cukup tinggi dalam setahun baik itu untuk manfaat langsung, manfaat tak langsung, manfaat keberadaan yang total nilainya sebesar Rp. 178596980.

Pohon lontar tidak saja mempunyai nilai manfaat dan ekonomi yang tinggi akan tetapi juga memiliki nilai penting bagi lingkungan yaitu sebagai penyerap karbon, yang mana dari hasil penelitian BPKK (Balai Penelitian Kehutanan Kupang) menunjukan besarnya karbon yang dapat diserap oleh pohon lontar dengan diameter $30 \mathrm{~cm}$ ke atas adalah sebesar 73,50 Ton/Ha.

\section{Daftar Pustaka}

Amalo, P. 2008. Multiguna, dari akar hingga nira. Media Indonesia. 21 November 2008BPTP NTT. 2006. Komoditas Unggulan Daerah NTT.

Fox, J. J., 1996. Panen Lontar, Perubahan Ekologi dalam Kehidupan Masyarakat Pulau Rote dan Sawu, Pustaka Sinar Harapan, Jakarta.

Hanley, N and C. L. Spash. 1993. Cost-Benefit Analysis and Environmental. Edward Elgar Publishing. England.

Kurniawan Hery dan yuniati Dhany. Potensi Simpanan Carbon Pada tiga Tipe Savana Di Nusa Tenggara Timur. Balai Penelitian Kehutanan Kupang. Kupang 2014.

Nazir, M., 1983. Metode Penelitian. Ghalia, Indonesia Jakarta.

Tambunan Parlindungan. 2010. Potensi dan KebijakanPengembangan Lontar Untuk Menambah Pendapatan Penduduk. Pusat Penelitian dan Pengembangan Hutan Tanaman. Bogor, Jawa Barat. 